\title{
Pleasure and dread: The paradox of travel
}

\author{
Dr. Jo Ankor
}

Received: 09/03/2011

${ }^{1}$ University of Technology Sydney, Australia, Phone: 0402761 748, e-mail: jankor@adam.com.au

Supervisor: Associate Professor Dr Stephen Wearing, School of Leisure, Tourism and Sport, Faculty of Business, University of Technology Sydney, Australia

Institution awarding the Ph. D. Degree: University of Technology Sydney, Australia Date of defence: $17^{\text {th }}$ July 2010

(C) 2011 International University College. All rights reserved

Citation: Ankor, J. (2011), Pleasure and dread: The paradox of travel. Doctoral dissertation summary. European Journal of Tourism Research 4(2), pp. 210-213

\section{Goal and objectives of the dissertation}

Both pleasure and dread lie in wait for the traveller. The willingness to embrace whichever of these may arise shapes the experience of travel. This thesis offers a multi-voiced exploration of this paradoxical relationship and seeks to develop a philosophical understanding of why we travel. Its intention is to expand the boundaries of tourism research methodologies and to suggest new ways of approaching the study of tourism.

This thesis begins in an observation of a personal experience of travelling by yacht, which brought contact with a group of people who had chosen to travel not because of what was known to be there, but precisely the opposite. This 'unknown', as destination, was chosen because it was not known what may be found or what might happen. These travellers had set out, willingly accepting whatever may occur, seeking to meet face-to-face with the people and places that may arise - an acceptance of the paradoxical presence of both pleasure and dread. The focus of tourism research, on attractions, sights and services for example, does not appear to include travel which has no framework or specified purpose and which is specifically open to the surprise of the unexpected and the potential of the unpredictable.

Drawing on cultural studies, creativity studies and philosophy, an exploration is made of the unexpected and unpredictable moments of travel.

\section{Methodology}

Tourism research is located across a number of academic disciplines and research paradigms. This thesis uses three analysis positions to attempt to represent the complexities of the travel experience. These comprise a review and analysis of literature and theory combined with a reflexive component that explores the theory and the use of a first-hand travel narrative of encountering difference and facing the unknown. It employs a critical theory approach. The three qualitative research approaches are interwoven to allow the reader a freedom of 
interpretation, much as the individual traveler must interpret the encounter. Tribe has described such an approach as a fusion of grounded theory, content analysis and researcher artistry (2008, p. 926). Through this dismantling of established approaches, concepts of the unknown and the other in travel can be re-examined.

\section{Results}

It was found that examining the moment of encounter in travel and applying philosophy of the face-to-face encounter with difference, or the unknown, provided a new understanding of outcomes of travel and therefore one of the reasons we choose to 'go'. The relationship of disparate conceptual bases - from sociological theory of creativity to tourism theories of the new traveller and philosophical examinations of the role of the other - was established and provided a deeper analysis of the nature of the travel encounter. It was concluded that the relationship of the individual and the 'other' lies at the heart of all travel and that the nexus of traveller, space and difference - self, context and other - is a key to understanding the travel choice to experience the unknown as destination.

\section{Theoretical conclusions}

The thesis began in an observation of the choice of the unknown as destination. The theory of a new kind of traveller, the neonomad, who wants to create experiences, theory that there are meeting points in travel, when the traveller's current understanding, the 'object' and a new context combine, and that has never occurred before, has brought the suggestion that such moments generate new ideas and therefore new meanings. Philosophy demonstrates that we continually make meaning for our lives, and that the relationship with the unknown and with the other, with difference, is critical to developing meaning.

It can be concluded that the unknown as destination is chosen for the increased opportunity for moments of encounter that change the traveller's individual perception of the world, that is, their subjectivity. This occurs because the nexus of alterity, the event and the responsive self allows fresh combinations of elements in the experience, to form new conceptualisations and ideas. The traveller subject then has a changed relationship to the world through the active positioning of the self for change.

The central conclusion of this thesis, then, is that travel offers the potential for moments that generate new ideas and therefore new meanings, altering the subjectivity of the traveller. The choice of the unknown as destination in travel is an acknowledgement of - and an eager engagement with - the understanding that the other's face forms me.

\section{Practical application of the dissertation}

This is a theoretical thesis applying critical analysis to the phenomenon of tourism. It was not undertaken as applied research and therefore its contribution is toward the conceptual analysis of travel and tourism.

\section{Content of the dissertation}

Abstract of section one: Tourism and Travel: Paradoxes in Theory

Examining the choice of a destination where it was not known what might be found or what might occur, means examining the expectations and experiences of travel. Reflexive methodologies such as criticalcreative research writing are used. The ambivalent position of the researcher who is examining human experience remains problematic in qualitative enquiry (Denzin 1997, Hutchinson \& Samdahl 2000). This is explored in Ways of seeing: the Researcher's Gaze, the first of the critical-creative research writing contributions.

References to a postmodern, nomadic traveller (MacCannell 1992, 2000; Clifford 1997; Horne 1992) who is interested in the unknown and the unexpected brings the suggestion that travel which consciously seeks the surprise of the unexpected offers moments of sudden insight or aperçu that can affect our personal meanings and understandings of the world. In Beginners' Choice, the Narrative describes making the choice of the unknown.

Abstract of section two: Choosing the Unknown: Paradoxical Nomads 
Articulating a travel choice where the unexpected is allowed to unfold, encounters two difficulties; firstly it is not easy to express, as the underlying motivations are conceptual rather than practical, and secondly, as an explanation, it makes people uncomfortable. Discourses develop within particular times and places which determine what it is possible to speak, write, or otherwise communicate (Foucault 1972) and the discourses of tourism are no exception. It is easier, Islam notes, to express and discuss travel choices in the context of extremes, to map the 'exorbitant differences ignited by nothing less than the spectacular' (1996: 157) than to express an intention of "being open to the surprise of the unexpected experience". The critical-creative research piece Telling Ways explores how words, including those from travel brochures, can take on different meanings depending on context while in Explaining It Away, the Narrative talks of reactions to the choice of the unknown.

\section{Abstract of section three: Encountering Difference: The Offer in the Moment}

The choice of the unknown offers the possibility of moments of sudden insight, if the traveller is responsive in the encounter with the difference of the other within those moments. The interaction in the moment, of the traveller, the other and the space, brings multiple factors into play - the embodied nature of travel, individual cultural knowledge, a relationship with difference and the perception of possibilities. These combine to offer a moment of changing awareness. Studies of creativity suggest that new ideas, that is, insightful perceptions and connections, are developed in the juxtaposition of existing knowledge, new elements and an openness to the possible combinations available (Csikszentmihalyi 1990). In travel, any new situation offers some elements are known to the visitor, but that at the same time, 'things are there as objects we contemplate but whose meanings in their local context we cannot grasp' (Suvantola 2002: 44). These question the traveller's place in the world and perhaps reveal possibilities of existence which were previously concealed (Garlick, 2002). If so, travel is an activity that enables the individual negotiation of identity and subjectivity through a non-reductive relation with the other. Losing the Horizon is a critical-creative representation of those moments of shifting recognition, of becoming different ourselves while the Narrative offers an exploration of these interactions of body, difference and environment in The Sailing Body - 'all' is it, there's no middle ground at sea!

Abstract of section four: Other and Event: Philosophy of Possibilities

The relationship of the self and the other, which is critical in the travel experience of encounter, is a contested one in philosophy. Levinas (1969) holds that the other is not the simple reversal of identity such as the mirror offers and is not formed out of resistance or the need to manage but is prior to every initiative. The powerful metaphor of the mirror in relationship to difference is explored in Regarding reflection: La réflexion regardée while the fourth Narrative, The Exotic Liminal - those others, being other, becoming other, shows a reflexive awareness of change.

The movement of the traveller into the unknown is an act that positions the self in a situation which holds the elements of a potential event, one that may change the self through the development of new ideas and conceptualisations. It is suggested, then, that the self is constituted through the relation to the unknown engendered in the moment of encounter. There is an active positioning of the self for change.

Abstract of section five: Travel for change: subjectivity and wonder

In recognising the other as integral to the notion of self (Garlick 2002), the self is understood as constituted through the relation to the unknown engendered in an unstable moment of rupture or disturbance. The subject, then, has a changed relationship to the world through the development of new meanings for their being in the world. The significance of powerful individual moments in making our subjectivity is explored in critical-creative writing in Talking of Great Matters and the responsive encounter with difference that 
allows wonder is recorded in the Narrative Casual Wonder. Examining the travel experience has identified the moment of encounter in travel when a person has to change; they cannot, by virtue of the real space they inhabit at this real-time moment, continue to be what they were up until this instant. The philosophical statement is therefore made that travel choice positions the person for the chance/unpredictable event which only lies in the encounter with the other, for the creative moment that alters subjectivity, thus allowing the other's face to form me.

Finally, Epilogue - Return to Known concludes the narrative's story.

\section{References}

Clifford, J. (1997). Routes: Travel and Translation in the Late Twentieth Century. Cambridge, MA: Harvard University Press.

Csikszentmihalyi, M. (1990). The domain of creativity. In M.A. Runco \& R.S. Albert
(Eds). Theories of Creativity. Newbury Park, CA: Sage, pp. 190-212.

Foucault, M. (1972). The Archaeology of Knowledge. London: Routledge.

Garlick, S. (2002). Revealing the Unseen: tourism, art and photography. Cultural Studies Review, 16(2), 289-305.

Horne, D. (1992). The Intelligent Tourist. McMahon's Point, NSW: Margaret Gee Publishing.

Islam, S.M. (1996). The ethics of travel: from Marco Polo to Kafka. Manchester, UK: Manchester University Press.

Levinas, E. (1969). Totality and infinity: an essay on exteriority. Trans. A. Lingis. Pittsburgh, Pennsylvania: Duquesne University Press.

MacCannell, D. (2002). The ego factor in tourism. Journal of Consumer Research, 29(1), 146-151.

Suvantola, J. (2002). Tourist's experience of place. Hampshire, England: Ashgate. 